\title{
Matthew 13 and the feasts of the LORD
}

\author{
Author: \\ Jacob J. Scholtz ${ }^{1}$ \\ Affiliation: \\ ${ }^{1}$ Discipline Group Old and \\ New Testament, Faculty \\ of Theology, Stellenbosch \\ University, South Africa

\section{Correspondence to:} \\ Jacob Scholtz \\ Email: \\ jacojanscholtz@gmail.com

\section{Postal address:} \\ 14 Botrivier Street, Protea \\ Valley, Bellville 7530, South \\ Africa

\section{Dates:} \\ Received: 09 Nov. 2014 \\ Accepted: 17 Mar. 2015 \\ Published: 30 Apr. 2015 \\ How to cite this article: \\ Scholtz, J.J., 2015, 'Matthew \\ 13 and the feasts of the, \\ LORD' In die Skriflig 49[1], Art. \\ \#1900, 8 pages. http://dx.doi. \\ org/10.4102/ids.v49i1.1900

\section{Note:} \\ This article is based on a \\ study at the Stellenbosch \\ University (Discipline Group \\ Old and New Testament, \\ Faculty of Theology).

\section{Copyright:} \\ (C) 2015. The Authors. \\ Licensee: AOSIS \\ OpenJournals. This work is \\ licensed under the Creative \\ Commons Attribution \\ License.
}

After summarising the results of reading Matthew 13 as a prophetic discourse containing 'new and old' prophecies that have been, or will still be, literally fulfilled, this article links the parables of Matthew 13 to the prophetic and typological fulfilment of the feasts of the LORD.

Matteus 13 en die feeste van die Here. Ná 'n samevatting van die resultate van 'n interpretasie van Matteus 13 as 'n profetiese diskoers wat 'nuwe en ou' profesieë bevat wat letterlik vervul is of nog vervul gaan word, word die verband tussen die gelykenisse van Matteus 13 en die profetiese en tipologiese vervulling van die feeste van die HerE aangetoon.

\section{Introduction}

In Matthew 13, Jesus presents mysteries of the kingdom of heaven, uttering things kept hidden since the foundation of the world (Mt 13:11, 35). By using parables, an indirect form of speech, Jesus fulfils prophecy (Mt 13:35; cf. Ps 78:2). The fulfilment of this prophecy, however, is likewise indirect, for when Matthew 13:35 refers to Psalm 78:2, a typological application is being made (Blomberg 1992:221; Turner 2008:347). As a type, Asaph juxtaposes the faithful and mighty acts of God with Israel's periodic bouts of faithlessness and unbelief (Ps 78; cf. Carson 1995:321); as the antitype, Jesus may be revealing the works of Christ to his disciples according to a divinely designed Old Testament pattern. In the first two articles of this three-part series, it was proposed that Matthew 13 could be read as a juxtaposition of 'new' prophecies about the first, spiritual phase of the kingdom of heaven with 'old' prophecies regarding its future, literal phase (Scholtz in press $a$; in press b). ${ }^{1}$ After first summarising the results of reading Matthew 13 as a discourse containing literal prophecies, this third article of the series again presents a reading of Matthew 13 as a prophetic discourse, but indicates how the 'new and old' can be linked to the prophetic and typological significance of the feasts of the LORD ( $\mathrm{Lv} 23$; Nm 28-29; Dt 16; cf. Ex 12). To do this, the second focus of this article is to briefly define and characterise typology, and, thirdly, the feasts of the LoRD are introduced. Fourthly, the 'new and old' prophecies of Matthew 13 are linked to the indirect and typological fulfilment of the feasts of the LORD.

The following presuppositions form the basis of the interpretative model proposed in this article: firstly, regardless of whether prophecies are considered to be literally or typologically fulfilled, the grammatical-historical method of interpretation is followed; secondly, a premillennial perspective is adhered to; thirdly, the Church is not considered to be the same as Israel; and fourthly, Edersheim (1994), who consulted the work of Josephus, Philo, the Mishnah, Maimonides and not a few other sources (cf. Edersheim 1994:ix-xi), reasonably accurately presents the way the feasts of the Lond were observed at the time of Christ's First Advent. Other sources seem to corroborate this presupposition (cf. Fuchs 1985; Carmichael 1991; Downie 1994).

\section{Matthew 13 and literal prophecies}

Matthew 3-12 is understood as depicting a valid offer of the kingdom of heaven to Israel..$^{2}$ If that generation in national Israel had collectively turned from their sins to God and accepted the Messiah as their King, all Israel would have been saved and the Davidic or Messianic kingdom would have been literally restored and established on earth (cf. Toussaint 1980:61, 138; Scholtz 2014:3). However, when 'this generation' in Israel committed the unpardonable sin,

\footnotetext{
1.Familiarity with the first two articles of this three-part series about Matthew 13 is recommended, because the same presupposition and research conclusions are assumed in this third article.

2.A detailed discussion of the offer of the kingdom, the unpardonable sin and the Davidic Covenant was presented elsewhere (Scholtz
} 2014:3-5) and also referred to in the first two articles of this series. 
TABLE 1: Matthew 13 and literal prophecies.

\begin{tabular}{|c|c|}
\hline Parable & Summary of interpretation \\
\hline Sower & $\begin{array}{l}\text { Even though Jesus is the primary sower, the word of the kingdom is sown from the days of John the Baptist until the end of the Tribulation Period, } \\
\text { depicting discipleship and fruit-bearing (or lack thereof). Disciples are given the mysteries of the kingdom - something 'new' never before directly } \\
\text { revealed, which prophets and righteous people of the Old Testament did not perceive. }\end{array}$ \\
\hline Tares & $\begin{array}{l}\text { The Son of Man authorises the } 11 \text { (later } 12 \text { again) disciples to start carrying out the great commission in 'his' field, which is the world. Instead of } \\
\text { the establishment of the literal kingdom, the first, spiritual phase of the kingdom of heaven, in terms of the New Covenant, exists from Christ's } \\
\text { cross onwards. The prophesied judgement of the tares immediately preceding the establishment of the literal kingdom has been delayed. The 'old' } \\
\text { prophecy that 'all Israel will be saved' in terms of the New Covenant remains to be fulfilled just before the Messianic kingdom is established. }\end{array}$ \\
\hline Mustard seed & $\begin{array}{l}\text { The Son of Man 'sowed' the apostle Peter into his field, which is the world. Using the keys he was given by Christ, Peter opens the spiritual door of } \\
\text { the kingdom of heaven to Jewish, Samaritan and Gentile believers. Just as the kingdom will grow into a large tree during its first, spiritual phase, so } \\
\text { too (in terms of an 'old' prophecy) will the restored Davidic kingdom grow into a large cedar tree during the millennium. }\end{array}$ \\
\hline Leaven & $\begin{array}{l}\text { The Holy Spirit baptises Jewish, Samaritan and Gentile believers into Christ's body until all has been leavened. The 'new' refers to Spirit baptism } \\
\text { during the first, spiritual phase of the kingdom, but the 'old' prophecy will still be fulfilled, namely that the Holy Spirit will be poured out on Israel } \\
\text { just before the establishment of the Messianic kingdom. The growth of the kingdom of heaven is due to the power of God. }\end{array}$ \\
\hline $\begin{array}{l}\text { Hidden treasure and Pearl } \\
\text { merchant }\end{array}$ & $\begin{array}{l}\text { Jesus is the man who finds and then hides the treasure, and he is also the merchant who bought the pearl. The field is again viewed as the world. } \\
\text { Buying and selling (bought and sold) refers to the crucifixion. Jesus Christ authenticates his authority and power (the 'treasure') to rule as King in } \\
\text { terms of the Davidic Covenant. When 'this generation' in Israel commits the unpardonable sin, the treasure is hidden and Christ goes to the cross to } \\
\text { provide the sign of the prophet Jonah. According to various 'old' prophecies, the treasure will be revealed for all to see from Christ's Second Advent } \\
\text { onwards. Having been to the cross, as the first, spiritual phase of the kingdom commences, the merchant Christ Jesus starts his 'pearl ministry' as } \\
\text { High Priest according to the order of Melchizedek in terms of the New Covenant. }\end{array}$ \\
\hline Dragnet & $\begin{array}{l}\text { The Son of Man oversees the activities with the dragnet during the Tribulation Period. In view is the transition from the first, spiritual phase of } \\
\text { the kingdom into its future, literal phase. At the end of this age, the wicked (chaff, tares, bad fish) will be excluded from the kingdom when it is } \\
\text { established. }\end{array}$ \\
\hline House-holder & $\begin{array}{l}\text { Jesus Christ is the primary householder who teaches 'new and old' things concerning the kingdom of heaven with authority. Disciples who receive } \\
\text { understanding of all these things must store it in their hearts and then teach it with the authority they have been given. }\end{array}$ \\
\hline
\end{tabular}

the establishment of the kingdom in terms of the Davidic Covenant was postponed (Mt 12:23-45). ${ }^{3}$ This development neither surprised God nor did it interrupt his redemption and kingdom program, for it was always part of God's divine plan (Pentecost 1964:133-145). Even though the nation of Israel has temporarily been set aside as the vehicle through which God will accomplish his purposes on earth (cf. Mt 12:46-50; 13:14-15), eventually God will fulfil the unconditional promises he made to Israel in terms of the Abrahamic, Land, Davidic and New Covenants. In the wider context of the Old and New Testaments, the Church is viewed as the bride of Christ (2 Cor 11:2; Eph 5:23-33); Israel is viewed as the estranged wife of $\mathrm{YHWH}$ who will in future be reunited with her Husband in terms of the New Covenant (Jr 31:31-37; Hs 2:2; Fruchtenbaum 2004:667). Until a future generation of Israelites will turn from their sins to God and accept the Messiah as their King (Hs 5:15-6:3; Zch 12:10; Mt 23:39; cf. Toussaint 1980:265-266), the kingdom of heaven cannot exist in a national, Davidic form, but it can exist spiritually. ${ }^{4}$

The first, spiritual phase of the kingdom of heaven can be understood to exist in terms of the New Covenant from Christ's crucifixion and onwards. The future, literal phase of the kingdom of heaven (the 'not-yet' phase) will be established on earth in terms of the Davidic Covenant at Christ's Second Advent. Except for the parable of the sower, which includes a transitional component from the days

3.The unpardonable sin was a national sin committed by the generation living in Israel during Christ's First Advent (cf. Scholtz 2014:4-5). Individual Jews of that generation could still avoid the judgement of $A D 70$ by changing their minds about who Jesus is and trusting in him as their Saviour (cf. Mt 12:32a; Ac 2:40). The unpardonable sin does not mean Israel as a nation has permanently been set aside by God. Towards the end of the Tribulation Period, all Israel will be saved in terms of the New Covenant (Jr 31:31-34; Rm 11:25-27; cf. Mt 23:39) and this saved and restored nation will be used by God in the millennium as a blessing to other nations. The author rejects all forms of supersessionism and anti-Semitism.

4.The nature of the kingdom of heaven has not unalterably been changed into a spiritual kingdom only, for Saucy (1997:335) fittingly points out that this development does not mean 'that the original character of the Kingdom as Jewish, historical, and political was necessarily abandoned with the mystery-teaching of the historical, and political was necessarily abandoned with the mystery-teaching of the
Kingdom. Rending the physical from the spiritual is the non-chiliast's error ... the Kingdom. Rending the physical from the spiritual is the non-chiliast's error
error Jesus repudiates in his particular teaching on the Kingdom's futurity'. of John and onwards, most of the 'new' in the parables of Matthew 13 can best be viewed as prophetic relative to the day on which Jesus presents them (Mt 13:1, 16-17, 35-36, 53). The 'old' in these parables is understood as unconditional and as yet unfulfilled Old Testament prophecies regarding the establishment of the kingdom of heaven (cf. Toussaint 1980:175-176). In the first two articles of this series, specific, prophetic referents were identified to aid the understanding of the prophecies contained in the parables of Matthew 13, and the results of those studies are in Table 1.

\section{Typology in general}

Linking the 'new and old' in Matthew 13 to the typological fulfilment of the feasts of the LORD requires some brief comments about typology. The following two definitions appear to capture the essence of a type. A type can be described as an 'Old Testament institution, event, person, object or ceremony which has reality and purpose in Biblical history, but which also by divine design foreshadows something yet to be revealed' (Campbell cited by Tan 2000:80). Beale (2012:57) defines typology as the study of 'analogical correspondences among revealed truths about persons, events, institutions, and other things within the historical framework of God's special revelation, which, from a retrospective view, are of a prophetic nature'.

What characterises a type? Analogical correspondence or resemblance is often noted by commentators (Kaiser 2001:106; Beale 2012:57), but so too is dissimilarity, for there is 'no oneto-one correspondence between type and antitype' (Ramm 1970:228; cf. Pentecost 1964:53). Since a 'type never equals its antitype', when Scripture calls Christ our Passover Lamb (1 Cor 5:7), that does not make Jesus a lamb (Tan 2000:81). Somewhat related to dissimilarity is the characteristic of escalation: '[T]here is just as strong evidence of discontinuity in that the new exceeds and outstrips the forerunner in its clarity, implications, or applications of its effects' (Kaiser 
2001:106). According to Tan (2000:81), Passover lambs were vicariously slain in Jewish homes on the night of the Exodus, but this historical event has a higher application, for the Passover lamb of the Jews is a type of Christ, the Lamb of God.

Historicity is an important characteristic of types, since 'it is essential that the OT type be grounded in a real historical context' (Kaiser 2001:106; cf. Beale 2012:57). This allows 'the unfolding of the literal base of the type, not the allegorization of what is typified' (Tan 2000:81). Both prophecies and types can be called 'prophetic', but they differ in form: prophecy verbally delineates the future in words and statements, but a type is expressed in events, persons, and acts (Pentecost 1964:52; cf. Ramm 1970:216, 229). According to Beale (2012:17), verbal prophecy is 'directly fulfilled, whereas typological foreshadowings are viewed to be indirectly fulfilled'.

There must be evidence that the type was designed and appointed by God to represent the thing typified (Ramm 1970:228). Kaiser (2001:110) states that when 'God specially designated events, institutions, and persons, he did so because they had a certain necessity about them that pointed beyond their times to another future time and generation'. A divinely designated type clearly exists when the New Testament expressly states it (cf. Tan 2000:82).

\section{The feasts of the LORD introduced}

Fuchs (1985:10) holds that the feasts of the LoRD constitute not only a list of holy days, but 'actually an outline of God's calendar from eternity to eternity'. More specifically, these feasts can be said to trace 'the unfolding of God's redemptive purpose through the ages' (Downie 1994:16). Regarding Leviticus 23 and the New Testament, nowhere 'is the continuity between the testaments so clear as in the [festival] calendar' (Wenham 1979:306). As will be discussed below, the historical and retrospective function of these feasts can be seen in the Old Testament, but according to Fruchtenbaum (2005), the prophetic and typological significance of the feasts of the LORD also provide

$[A] n$ outline of the entire program of redemption, from the death of Yeshua (Jesus) to the establishment of the Messianic Kingdom. The first four festivals were fulfilled by the program of the First Coming, while the last three festivals of Leviticus 23 will be fulfilled by the program of the Second Coming. (p. 5; cf. Fuchs 1985:11-13; Nadler 2010:4-5; Malan 2012:9-17)

The feasts of the LORD are prominently mentioned in Leviticus 23, Numbers 28-29 and Deuteronomy 16. ${ }^{5}$ Whereas Deuteronomy 16 'stresses the pilgrimages to the feasts, Numbers 28-29 emphasizes the offerings, and Leviticus 23 focuses on the feasts themselves' (Hui 1990:144). Leviticus 23 describes the Sabbath together with seven feasts, namely the Feast of Passover, the Feast of Unleavened Bread, the Feast of Firstfruits, the Feast of the Harvest, the Feast of Trumpets, the Day of Atonement and the Feast of Tabernacles. These feasts of the LORD are 'appointed seasons' for 'holy convocations' 5.Numerous other Oid Testament references to these feasts are not noted here.

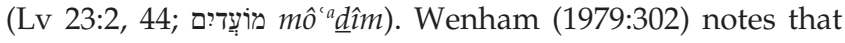
according to Genesis 1:14, the sun and moon were created to be for 'signs and seasons' (literally 'meetings', or in Hebrew מוֹ $m \hat{\text { מ }}$ ' 'éd); in Leviticus 23:2, 4 and 44, reference is made to the Lord's 'meetings', and in verse 37 to 'appointed seasons' (מוֹ $m \hat{o}^{\text {a }}$ dîm). From the cross until his Second Advent to the earth, Jesus Christ typologically fulfilled, or will still fulfil, the feasts of the LORD not in terms of the Mosaic Covenant according to the Aaronic priesthood, but in terms of the New Covenant as High Priest according to the order of Melchizedek.

According to Keil (cited by Hui 1990:154), 'the Sabbath is the governing principle in the feasts of the LORD' and this annual cycle of feasts had 'its centre and starting point in the Sabbath'. The Sabbath basically means to rest or to cease from work. God rests from his work of creation on the seventh day (Gn 2:3), but, since the entrance of sin, God has been working to achieve his redemption and kingdom programmes (cf. Jn 5:17). As depicted in the history of Old Testament believers and Israel, God is not only working to provide redemption rest out of Egypt, but also 'Canaan rest' in the Promised Land. 'Canaan rest' means to 'cease struggling with the enemy', this 'type of rest enables the believer to conquer $\sin ^{\prime}$ and 'Canaan rest' is 'a symbol of consecration rest', having to do with the 'subjection of one's mind, one's will, and one's heart to God's power' (Fruchtenbaum 2005c:44). Referring to Psalm 95, the privilege to 'enter into My rest' (v. 11) may be understood, as Gleason (2000:297) argues, 'as the right to worship before the personal presence of Yahweh (vv. 2, 6), which could be forfeited by hardened, rebellious hearts like those of the Exodus generation (vv. 8-10)'. If New Testament believers remain faithful, they can joyfully and confidently approach the throne of grace, where Jesus Christ their High Priest makes intercession for them (cf. Gleason 2000:301-303). A further Sabbath rest awaits the believer, which will be partially realised during the millennium (Ritchie 1982:24-27; Nadler 2010:15) and fully realised in the eternal state (Downie 1994:31).

The Sabbath of the Mosaic Covenant commemorates that God ceased working after six days of creation (Ex 20:11), but the Law of Moses also commemorates redemption rest out of Egypt (Dt 5:15). Edersheim (1994:166; cf. Fuchs 1985:17) stresses that the Mishnah (Pes. ix. 5) distinguishes between the 'Egyptian' and 'Permanent' Passover. The Egyptian Passover is described in Exodus 12, where the lamb is eaten in haste as the Israelites are not yet redeemed by the LORD from slavery out of Egypt. Having been baptised into Moses in the cloud and in the sea (cf. 1 Cor 10:2), a redeemed Israel arrives at Sinai where, based on the Mosaic Covenant, the theocratic kingdom commences. The 'Permanent Passover' is part of the feasts of the LORD commemorated by redeemed servants of YHWH (cf. Lv 23:5-8). Since most of the feasts of the LoRD described in Leviticus 23 could not be observed until Israel was in the Promised Land, Hui (1990:151) argues that these feasts 'emphasize not the leaving of Egypt, but the entrance into the Promised Land ...' 
The New Testament testifies to a divinely designed correspondence between the works of Christ and the typological fulfilment of the Feasts of Passover (cf. Lv 23:4-5; Jn 1:29, 35-36; 1 Cor 5:7; 1 Pt 1:18-19; Rv 5:12), Unleavened Bread (cf. Lv 23:6-8; 1 Cor 5:6-8; Heb 9:11-10:18; 1 Jn 1:10), Firstfruits (cf. Lv 23:9-14; 1 Cor 15:20-24) and Harvest (cf. Lv 23:15-21; Ac 2:1-4; cf. 11:15-17). The typological fulfilment of these four feasts corresponds to what has previously been argued as the beginning of the first, spiritual phase of the kingdom of heaven (Scholtz in press a). Following Christ's crucifixion, burial and resurrection (cf. the parables of the hidden treasure and pearl), on the day 'Pentecost had fully come' (Ac 2:1), when the kingdom of heaven 'had become like' a field sown with good seed (Mt 13:24) as described in the parable of the tares in the field, Christ Jesus as High Priest started to dispense spiritual blessings to his followers via the Holy Spirit (cf. the parables of the mustard seed, leaven and pearl).

If the first four feasts of the LORD have been typologically fulfilled by Christ in chronological order, why should the 'shadow of things to come' - the prophetic and typological significance of the Feast of Trumpets on a new moon, the Day of Atonement and the Feast of Tabernacles - not also find their substance in Christ (Lv 23:23-43; cf. Col 2:17; Kellogg 1940:354-355; Fuchs 1985:41)? ${ }^{6}$ Can these autumn feasts and Day of Atonement season be linked typologically to aspects of the parables of Matthew 13, to a time when 'all has been leavened' (Mt 13:33), when the firstfruits of the 'pearl ministry' have been taken to the Bridegroom (Mt 13:45-46; cf. 9:15), or to a time when the dragnet is thrown into the sea of nations just before the end of this age (Mt 13:47-50)?

\section{Matthew 13 and typological prophecies}

\section{The Feasts of Passover and Unleavened Bread}

God announces his redemptive work on behalf of Israel when he promises Abraham that his descendants will be redeemed out of a foreign land and brought into the land he has given to Abraham (Gn 15:13-16; cf. Ex 2:24). When the new king of Egypt (who did not know Joseph) instructs the midwives to kill new-born Israelite boys, they did not obey, because they feared God. However, the king still has his command executed (Ex 1:8, 15-22). One baby is physically saved by being drawn out of the water and it is this Moses whom God calls so that the nation of Israel, 'My son, My firstborn', will not only be delivered from Egypt, but will also enter the Promised Land (cf. Ex 4:22). Moses is given various signs and wonders so that the Israelites will believe that God has appeared to him (Ex 3:1-4:31). After nine plagues, Pharaoh's heart is still hardened, and God speaks to Moses and Aaron to command the Israelites to sacrifice a lamb and place some of its blood on the doorposts and lintel of the house (Ex 12:1-28). The LoRD's Passover and the Feast of Unleavened Bread are instituted before Israel is redeemed out of Egypt,

6.The Feast of Tabernacles has not been fulfilled nationally, but it has been fulfilled in the lives of individual Christians from Pentecost onwards when the Holy Spirit's ministry of permanent indwelling of all believers began (cf. Jn 7:37-39; Nadler 2010:160). before the giving of the Mosaic Covenant at Sinai and before Israel enters the Promised Land.

Not only should it accept the king that God sets over them, but God also commands Israel to heed the Prophet like Moses whom he will send (Dt 17:15; 18:15-19; cf. Mt 3:16-17; 13:57). The Gospel of Matthew is replete with examples of how Christ fulfils Scripture, but the correspondences between Moses, the type, and Christ, the antitype, are particularly evident in Matthew 1-13. When Herod (who presumably did not know Joseph) hears about the King of the Jews, he kills Jewish boys, but the wise men from the east heed God (Mt 2:1-12; cf. Ex 1:8, 15-22). The young Child, however, is physically saved, for God has called Jesus not only to save his people from their sins (thus out of the Egypt of this world), but also to lead them as Davidic king into the Promised Land in the Messianic kingdom (cf. Ex 4:22; Mt 1:21; 4:7). Like Moses, Christ 'went up out of the water' at his baptism (Mt 3:13-17; Ex 2:10). Will Christ also initially be rejected as prince and ruler over the Hebrews as Moses was (cf. Ex 2:14; Ac 7:25-27)? Just as Moses was given various signs and wonders so that the people would believe that God had appeared to him, Immanuel authenticates his Person (He is Jesus the Messiah) as well as his message about the gospel of the kingdom (Mt 4:17-11:1a; cf. Ex 3:1-4:31). Instead of ten plagues, Matthew 8-9 lists ten or so miracles that Jesus performs (Toussaint 1980:122).

According to Barrick (1999:228), when Israel was sent into exile to Babylon to chastise them for their rebellion, 'Israel's history of national deliverance (Ex 19:4) was converted into a history of national exile (Lv 26:33, 38). In a sense, they had returned to their previous bondage.' Is the kingdom of heaven that Christ is offering 'this generation' in Israel a spiritual kingdom only along with moral-ethical-social implications, or a literal kingdom on earth, which will, in addition to the above, also include political-theocratic-governmental aspects? Jesus offers 'this generation' not only redemption out of the 'Egypt' of this world with its kingdoms and its glory (cf. Mt $1: 21 ; 4: 8 ; 12: 26)$, but the King also offers to establish them in the Promised Land in the Messianic kingdom. ${ }^{7}$

For all Israel to be saved (Is 32:15-20; Jr 31:31-34; Ezk 39:25-29; Jl 2:28-3:1; Zch 12:8-13:1) and to again become a redeemed people would have required 'this (Jewish) generation' to apply the blood of the Lamb of God on the doorposts of their hearts. Furthermore, 'this generation' in Israel had to accept the King anointed by the LoRD (Dt 17:14-20; Mt 3:16-17; Lk 1:32-33). Because 'Christ came to offer the kingdom by way of the cross' (Toussaint 1980:64), the death of the Messiah was a divine necessity, regardless of 'this generation's' response. Even so, if 'this generation' had believed Christ, the Davidic kingdom would have been established (cf. Scholtz 2014:3-4). However, the Messiah was neither accepted as King nor honoured as the Prophet like Moses (cf. Mt 13:57). Thus, at some stage a future Jewish generation will have to look to the One whom they have

7.As the Son of Abraham (Mt 1:1), Christ will fulfil all unconditional promises that God made in the Abrahamic Covenant, including those relating to the land of Israel (Gn 15:18-21; cf. Vlach 2014:33). 
pierced (Zch 12:10; cf. Hs 5:15) and confess Israel's national offense (Is 53:1-9; cf. Mt 23:39) so that the Day of Atonement season will typologically be fulfilled.

Given the indifference of 'this generation' in Israel to the message of 'more than a prophet' who announces God's anointed King, and following even cities' failure to repent (Mt 11:2-24), it seems that the Gospel of Matthew starts to anticipate some of the Permanent Passover proceedings en route to the cross (cf. Edersheim 1994:171-196; Nadler 2010:20-59). Reminiscent of words used during the Passover Seder proceedings, in Matthew 11:25 Jesus thanks the Lord of heaven and earth, that is, the King of the universe. A contrast between different sons or disciples are made (cf. Carmichael 1991:50), for God the Father hides the works of Christ to those wise and clever in their own eyes, but reveals them to children (Mt 11:25). It is these children - disciples of Christ who do the will of the Father - who justify wisdom by trusting in the Lamb of God and removing leaven through repentance (cf. Mt 11:19b; 12:50; 21:28-32). For them the festival-lights will truly be kindled by the Messiah (Mk 4:21-22). Moreover, these redeemed children will understand the allusion to the Trinity when three pieces of matzah (הָָָ mașâ) are placed onto the special Seder plate or into the bread bag, the matzah tash (cf. Fruchtenbaum 2005b:17; Nadler 2010:29-30), for God the Father can only be known through the Son and by those to whom the Son wants to reveal him. During Jesus' First Advent, Christ reveals the Trinity through his various works performed by the Spirit of God (Mt 11:27; 12:28).

The four sections of the Seder are commemorated by drinking from four cups (Edersheim 1994:185; Nadler 2010:27-28). Indicative of the first and second cup, the Lord of the Sabbath (Mt 12:8) invites individuals to find redemption rest (Mt 11:28) as well as 'Canaan rest' in him (Mt 11:29-30). Still in anticipation of the Passover Seder proceedings, when the head of the house takes the middle piece of matzah, breaks it and wraps one part in a cloth and hides it, the children who have already left Egypt will find this afikoman (אפיקומן 'â̂pqômān), for they have placed their faith and trust in the Suffering Servant (cf. Mt 12:18-21; Edersheim 1994:187; Nadler 2010:47-48). The child who finds the afikoman first is given a special blessing by the Father. 'Daube, agreeing with Eisler, translates the word afikoman as straightforwardly derived from the Greek afikomenos, which means "The Coming One", or "He that has come"' (Carmichael 1991:53). Later, at the actual Passover meal, Jesus takes the now-found afikoman piece and breaks this unleavened, striped and pierced bread, and gives it to his followers, saying 'Take, eat; this is My body', and later 'Drink from it, all of you'. His followers will later do this to commemorate this holy communion, proclaiming the Lord's death until he to whom the afikoman points, comes again (cf. Mt 26:26-27; Jn 6:35, 53-58; 1 Cor 11:24-26). When baptised by the Holy Spirit into the body of Christ, believers identify with Christ's death, burial and resurrection, which fulfilled the Feasts of Passover, Unleavened Bread and Firstfruits. Whereas the breaking of the middle piece of matzah represents Christ's death, and the wrapping in cloth represents his burial (Mt 27:59), the third cup of redemption represents Christ's resurrection on the third day, signifying spiritual redemption (cf. Mt 26:27-28; Fruchtenbaum 2005b:32-33). The Coming One is going to take his followers and only then will he drink the fourth cup of praise 'with you in My Father's kingdom' (Mt 26:29; cf. 13:43; Nadler 2010:28).

Peter first identifies the afikoman as Jesus Christ, the Son of the living God. This is revealed to him by the Father, and he receives a special blessing - notably the keys of the kingdom of heaven (Mt 16:16-19). After the Feast of the Passover has typologically been fulfilled by the Lamb of God, redeemed children will eventually understand the typological and prophetic fulfilment of this feast (cf. Mk 9:32; Lk 18:34; Jn 1:29). To those who already understand, more of the mysteries of the kingdom of heaven are given (Mt 13:11-12). None of the feasts of the LoRD can really be understood unless the blood of the Lamb of God is by faith applied to the doorposts of one's heart; none of the parables can really be understood unless the parable of the sower is understood (Mk 4:13). 'This generation' in Israel rejected Jesus and committed the unpardonable sin (Mt 12:23-45), and so they failed to even leave 'Egypt'. To them, the mysteries of the kingdom of heaven remain hidden (Mt 13:13-15), even as a surprising new development takes place, that is, the first, spiritual phase of the kingdom of heaven, which begins at the crucifixion, burial and resurrection of Christ with the harvest expanding from Pentecost onwards. These mysteries are not given to 'this generation' but one sign is, namely the sign of the prophet Jonah, so that at least some of them will leave 'Egypt' individually (Mt 11:28-30; 12:39-40; 13:11).

\section{The Feasts of Firstfruits and the Harvest}

One sheaf (עמִר 'omer) of firstfruits of the barley harvest is waved before YHWH on the first morning after the Sabbath (Lv 23:10-11; cf. Mt 28:1; Jn 20:17). God is thanked for his provision, and as the consecration of this first fruit is acceptable, the whole harvest is likewise acceptable to him (cf. Fuchs 1985:31; Edersheim 1994:203-205). The Feast of Firstfruits is observed on the first day of the week (Lv 23:10-11; cf. Ex 23:19; Dt 8:7-9), not in Egypt, but in the Promised Land (Lv 23:10a). The firstfruits from Passover until the day of Pentecost are collectively referred to as the spring harvest (Fruchtenbaum 2005a:12).

After shedding his blood on the cross and offering his sinless body as a sacrifice, Christ fulfils the Feast of Firstfruits by his resurrection, the 'firstfruits' of them who are 'asleep', the 'firstborn from the dead' (1 Cor 15:20; Col 1:18; cf. Ritchie 1982:40). Since a grain has fallen into the ground and died, it does not remain alone, but produces much grain, for the Son is the firstborn amongst many who receive the firstfruits of the Spirit (cf. Jn 12:24; Rm 8:23, 29b).

According to 'unanimous Jewish tradition, which was universally received at the time of Christ, the day of Pentecost 
was the anniversary of the giving of the Law on Mount Sinai' (Edersheim 1994:206; cf. Fuchs 1985:36). Just as the giving of the Mosaic Covenant formed the basis of the theocratic kingdom, so the first, spiritual phase of the kingdom of heaven commenced in terms of the New Covenant on the day that Pentecost had fully come (cf. Ac 2:1). Both the LorD's Passover and the Feast of Unleavened Bread are fulfilled by Christ before the first, spiritual phase of the kingdom of heaven comes into existence, before the giving of the New Covenant on the day the Feast of the Harvest is typologically fulfilled, before the establishment of the Davidic Kingdom in the age to come.

In accordance with the prescriptions for the Feast of the Harvest (or Pentecost), two loaves are baked with leaven ( $\mathrm{Lv}$ 23:17). This offering of two loaves is presented along with several other sacrifices, including a peace offering ( $\mathrm{Lv}$ 23:19; Nadler 2010:90). Whereas the Law of Moses acted as a middle wall of partition to keep Gentiles (as Gentiles) from the spiritual blessings of Israel's unconditional covenants (cf. Eph 2:11-18; Ritchie 1982:48), Jesus as our peace offering broke down the wall of separation (Eph 2:14). "The two loaves point to the fact that God is gathering out from Jew and Gentile, a people for Himself' (Ritchie 1982:48; cf. Downie 1994:81).

As previously argued (Scholtz in press a), the Son of Man sows a mustard seed into his field, that is, the apostle Peter is blessed, because the Father first revealed the afikoman to him. With the keys that Christ gave him, Peter opens the spiritual door of the kingdom of heaven to Jewish, Samaritan and Gentile believers as the first, spiritual phase of the kingdom of heaven commences (Ac 2:1-4; 8:14-17; 10; 11:15-17).

When Jesus prophesied that he will build his Church, he was using the future tense, indicating that the Church had not yet come into existence (Mt 16:18). In terms of the New Covenant, the Church was born on the day the Feast of Pentecost was typologically fulfilled, the day the Holy Spirit commenced a new ministry of baptism (Mt 3:11; Ac 1:5; 2:1-4; 11:15-17). The Holy Spirit baptises the two loaves - circumcised (Jews and Samaritans) and uncircumcised (Gentile) believers - 'in Christ', forming the body of Christ (1 Cor 12:12-13; Eph 1:22-23). According to Lightner (1996:172), 'Spirit baptism began on the Day of Pentecost and will be concluded at the time of the rapture of the church'. When this ministry of baptism ends, 'all will have been leavened' (cf. Mt 13:33). When the rapture occurs, the dead 'in Christ' will rise first, immediately followed by those believers 'in Christ' who are still physically living (1 Th 4:15-17).

The wheat from Pentecost onwards until it is gathered, is viewed as the summer harvest, distinguishing it from the spring harvest preceding it and the late autumn harvest depicted in the autumn feasts celebrated subsequently. During the summer harvest, from the Feast of Pentecost until the Feast of Trumpets, no other feast has to be observed
(Col 2:16; Malan 2012:29; Ritchie 1982:53-55). However, the Church commemorates the typological fulfilment of the first four feasts of Leviticus 23 by the ordinance of the Lord's Supper and by the ordinance of baptising disciples of Christ (Mt 26:26-28; 28:19).

In light of the typological fulfilment of the first four feasts, the following interpretative model is cautiously proposed for the typological fulfilment of the remaining feasts: the Feast of Trumpets will be fulfilled by the rapture of the Church; the Day of Atonement season will be fulfilled by the Tribulation (culminating in the national salvation and atonement of Israel); and the Feast of Tabernacles will be fulfilled by the establishment of the Messianic kingdom (Ritchie 1982:78-79; Fuchs 1985:13; Malan 2012:125-144). ${ }^{8}$

\section{The Feast of Trumpets, the Day of Atonement and the Feast of Tabernacles}

The Feast of Trumpets is mentioned only a few times in the Old Testament (Lv 23:23-25; Nm 29:1-6; Ezr 3:1-6; Neh 8:1-12; Ps 81:3-4). Since this feast occurs on the first day of the seventh month, the requirements of a New Moon festival should also be observed, as noted in Numbers 10:1-10 (cf. Nm 28:11-15). Whereas the Feast of Trumpets is not explicitly mentioned in the New Testament, a New Moon festival is mentioned in passing ( $\mathrm{Col} 2: 16)$. The only recorded observation of the Feast of Trumpets in Scripture is when exiled Jews return to Israel in the time of Ezra (Ezr 3:1-6). Various reasons for the blowing of trumpets are noted: a call to assembly or for war; a command for Israel to move out; preparation for an announcement; a warning of judgement to come; or a call to celebration and worship (Nadler 2010:108; cf. Fuchs 1985:47).

According to Fruchtenbaum (2005a:20; cf. Ritchie 1982:56-59; Malan 2012:130-142), the prophetic significance of the Feast of Trumpets is twofold: the sudden rapture of the Church when the last trumpet (tekiah gedolah) sounds, but also the worldwide gathering of Israel, still in unbelief, for the seven-year Tribulation Period. Referring to the prophetic significance of the two trumpets of the New Moon festival of Numbers 10:10, Downie (1994) proposes that one trumpet will blow for the Church and the other for Israel:

In the one, we may have the 'gospel of grace of God', in the other 'the gospel of the kingdom'. ... This testimony [of the gospel of grace] will go on until the Church is taken to heaven ... Then, when the Church has gone, God will resume His dealings with his earthly people [Israel] and, through them, the gospel of the kingdom will be preached throughout the whole world. (p. 99)

During the time of the summer harvest, the firstfruits of Christ's 'pearl ministry' - as a result of his side being pierced whilst he was asleep on the cross - are fashioned into a bride. During the first, spiritual phase of the kingdom, believers are still wandering in the wilderness of a world 8.The author appreciates that different views exist regarding the typological fulfilment of the Feast of Trumpets. 
TABLE 2: Matthew 13 and typological prophecies.

\begin{tabular}{ll}
\hline Parable & Summary of interpretation \\
\hline Sower & $\begin{array}{l}\text { God has been the primary sower of the gospel since the Fall. The four soils of the parable of the sower are reminiscent of the four } \\
\text { courses, four cups, four sons and four questions of the Passover Seder. Without faith in the Lamb of God, neither the parables } \\
\text { and mysteries of Matthew } 13 \text { nor the typological fulfilment of the feasts of the LORD can be properly understood. The feasts } \\
\text { foreshadow the substance that belongs to Christ who typologically fulfilled, or will still fulfil, the appointed meetings or seasons. }\end{array}$ \\
$\begin{array}{ll}\text { Christ typologically fulfils the Feast of Pentecost by sending the Holy Spirit to commence a ministry of baptism. Being the first to } \\
\text { identify the afikoman, Peter is given a special blessing to open the spiritual door of the kingdom of heaven to Jewish, Samaritan } \\
\text { and Gentile believers. The Holy Spirit bakes two loaves (the circumcised Jewish and Samaritan believers and uncircumcised } \\
\text { Gentile believers) with leaven. This process will continue until all is leavened, until the Church is raptured in possible typological } \\
\text { fulfilment of the Feast of Trumpets on a New Moon festival. }\end{array}$ \\
$\begin{array}{ll}\text { Bidden providing the sign of the prophet Jonah, Jesus typologically fulfils the Feasts of Passover, Unleavened Bread and Firstfruits } \\
\text { by his death, burial and resurrection. As the merchant, Christ Jesus starts his 'pearl ministry' as High Priest in terms of the New } \\
\text { Covenant from the typological fulfilment of the Feast of Pentecost onwards. }\end{array}$ \\
$\begin{array}{l}\text { The typological fulfilment of the Feast of Trumpets may witness the rapture of the Church as well as the gathering of Israel, still } \\
\text { in unbelief, for the seven-year Tribulation Period. During the Tribulation Period, the autumn harvest will be gathered, all Israel } \\
\text { will be saved at the typological fulfilment of the Day of Atonement, but the wicked will be excluded when the King returns to } \\
\text { establish the Messianic kingdom, thus typologically fulfilling the Feast of Tabernacles. }\end{array}$ \\
$\begin{array}{l}\text { Once the 'new and old' prophecies have literally and typologically been fulfilled, disciples of Christ will be able to teach 'old and } \\
\text { new' things during the millennium. }\end{array}$ \\
\hline House-holder
\end{tabular}

system headed by the god of this age who is still sowing tares (cf. Mt 13:25; Jn 12:31;2 Cor 4:4). Those believers truly obedient to the Lord during this time of pilgrimage can look forward to receiving, like Joshua and Caleb, rewards of authority or treasure once the age to come has been established (cf. Mt 25:14-34). When the 'fullness of the Gentiles' has come in (cf. Rm 11:25; Downie 1994:111), when 'all has been leavened' (cf. Mt 13:33), then, at the sound of the last trumpet (1 Cor 15:52; cf. 1 Th 4:13-18; Nadler 2010:109-110; Ritchie 1982:57-58), the Holy Spirit's ministry of baptism will cease, for the bride will be raptured to her Bridegroom.

As proposed previously (Scholtz in press b), the parable of the dragnet has the Tribulation Period in view, that is, the time of the late autumn harvest, the transition from the first, spiritual phase of the kingdom of heaven to its future, literal phase. Jewish messengers will preach the gospel of the kingdom, this time as a witness to all the nations (Mt 24:14). Many 'old' prophecies en route to the establishment of kingdom of heaven will start to be fulfilled at that time. During the last days of the times of the Gentiles, there will be great affliction of body and soul, especially for Jews, for it is the time of Jacob's trouble (cf. Jr 30:7; Mt 10:16-42; 24:9-35). Although two-thirds of the Jews will be killed during the Tribulation Period (Zch 13:8), ultimately the generation of Israelites living during the Tribulation will accept Christ's substitutionary work of atonement on the cross (Is 52:13-53:12). In agreement with Fruchtenbaum (2005a:25; cf. Kellogg 1940:355), having been afflicted in body (Hs 5:15-6:3) and soul (Zch 13:8-9), the national regeneration of Israel will 'come by means of the afflictions of the Great Tribulation and that, in turn, will lead to Israel's confession of her national offense with the words of Isaiah 53:1-9'. At the end of the Great Tribulation, the Day of Atonement will typologically be fulfilled by Christ when all Israel will be saved, the Holy Spirit will be poured over them and they will call on the Lord in faith to return with these words: 'Blessed is He who comes in the Name of the LORD!'

When the Lord returns, the judgement of the nations will follow (Mt 25:31-46). The Feast of Tabernacles will be fulfilled in national form by the establishment of the Messianic kingdom (Ritchie 1982:67-71; Downie 1994:137-141). During the millennium, everyone who is left from all the nations will go up year after year to worship the King, the LoRD of hosts, and to celebrate the Feast of Tabernacles (Zch 14:16). ${ }^{9}$ Believers will have 'Canaan rest' and, when the millennium merges into the eternal state, they will have the 'Sabbath rest' in eternity.

Table 2 summarises the results of linking the 'new and old' of Matthew 13 to the typological fulfilment of the feasts of the LORD.

\section{Conclusion}

The conclusion of this three-part series is that Matthew 13 may be read as a prophetic discourse containing not only prophecies that have been or will still be literally fulfilled, but that Matthew 13 may also be linked to the typological fulfilment of the feasts of the LORD. The central figure is the Lord Jesus Christ whose mighty works regarding the existence of the first, spiritual phase of the kingdom may be juxtaposed to those regarding the establishment of the future, literal phase of the kingdom of heaven. From eternity until eternity, all the promises and glorious deeds of God are 'Yes' in Christ (cf. Ps 78:4; 2 Cor 1:20).

\section{Acknowledgements Competing interests}

The author declares that he has no financial or personal relationship(s) that may have inappropriately influenced him in writing this article.

\section{References}

Barrick, W.D., 1999, 'The Mosaic Covenant', The Master's Seminary Journal 10(2), 213-232.

Beale, G.K., 2012, Handbook on the New Testament use of the Old Testament: Exegesis and interpretation, Baker Academic, Grand Rapids.

9.Zechariah 14:17-19 speaks of the punishment of those nations who do not go up to Jerusalem to worship the King and to celebrate the Feast of Tabernacles. Clearly, the nations are not doing this today. Since death is the last enemy to be destroyed before the eternal state commences (1 Cor 15:24-28), Zechariah 14:17-19 can hardly have in view the eternal state, because there will be no sin requiring can hardly have in view the eternal state, because there will be no sin requiring
punishment. Consequently, it is proposed that Zechariah $14: 16-19$ speaks of the millennium. 
Blomberg, C.L., 1992, Matthew, The New American Commentary, vol. 22, B\&H Publishing Group, Nashville.

Carmichael, D.B., 1991, 'David Daube on the Eucharist and the Passover Seder', Journal for the Study of the New Testament 42, 45-67. http://dx.doi. org/10.1177/0142064X9101304203

Carson, D.A., 1995, Matthew chapters 1 through 12 \& Matthew chapters 13 through 28 , Zondervan Publishing House, Grand Rapids. (The expositor's Bible commentary with the New International Version of the Holy Bible).

Downie, H.K., 1994, Harvest festivals, Gospel Folio Press, St. West Port Colborne.

Edersheim, A., 1994, The temple: Its ministry and services, updated version, Hendrickson Publishers, Peabody.

Fruchtenbaum, A.G., 2004, The footsteps of the Messiah, Ariel Ministries, Tustin.

Fruchtenbaum, 2005a, 'The Feasts of Israel', in A Messianic Bible Study from Arie Ministries, vol. 62, pp. 1-30, Ariel Ministries, San Antonio.

Fruchtenbaum, 2005b, 'The Feast of Pesach (Passover)', in A Messianic Bible Study from Ariel Ministries, vol. 114, pp. 1-33, Ariel Ministries, San Antonio.

Fruchtenbaum, 2005c, The Messianic Jewish epistles: Hebrews, James, First Peter, Second Peter, Jude, Ariel Ministries, Tustin.

Fuchs, D., 1985, Israel's holy days in type and prophecy, Loizeauz Brothers, Neptune.

Gleason, R.C., 2000, 'The Old Testament background of rest in Hebrews 3:7-4:11', Bibliotheca Sacra 157(627), 281-303.

Hui, T.K., 1990, 'The purpose of Israel's annual Feasts', Bibliotheca Sacra 147(586), 143-154.

Kaiser, W.C., 2001, The uses of the Old Testament in the New, Wipf \& Stock Publishers, Eugene.

Kellogg S.H., 1940, 'The book of Leviticus', in W.R. Nicoll (ed.), The Expositor's Bible: A complete exposition of the Bible in six volumes, with index, vol. 1, pp. 237-379, Eerdmans, Grand Rapids.
Lightner, R., 1996, 'Baptism of the Holy Spirit', in M. Couch (ed.), Dictionary of premillennial theology, p. 172, Kregel Publications, Grand Rapids.

Malan, J.S., 2012, Die sewe feeste, Lux Verbi, Kaapstad.

Nadler, S., 2010, Messiah in the Feasts of Israel, Word of Messiah Ministries, Charlotte. Pentecost, J.D., 1964, Things to come: A study in Biblical eschatology, Zondervan, Grand Rapids.

Ramm, B., 1970, Protestant Biblical interpretation: A textbook of hermeneutics, 3rd revised edition, Baker Books, Grand Rapids.

Ritchie, J., 1982, Feasts of Jehovah, Kregel Publications, Kilmarnock.

Saucy, M.R., 1997, The kingdom of God in the teaching of Jesus: In 20th century theology, Word Publishing, Dallas.

Scholtz, J.J., 2014, 'The kingdom of heaven and Matthew 10', In die Skriflig 48(1), Art. $\# 1782$, 8 pages.

Scholtz, J.J., in press a, 'Reading Matthew 13 as a prophetic discourse: The four parables presented in public', In die Skriflig 49(1), Art. \#1870, 7 pages.

Scholtz, J.J., in press b, 'Reading Matthew 13 as a prophetic discourse: The four parables presented in private', In die Skriflig 49(1), Art. \#1887, 7 pages.

Tan, P.L., 2000, 'Symbols and types in prophecy', in M. Couch (ed.), An introduction to Classical Evangelical Hermeneutics: A guide to the history and practice of Biblical interpretation, pp. 71-86, Kregel Publications, Grand Rapids.

Toussaint, S.D., 1980, Behold the King: A study of Matthew, Kregel Publications, Grand Rapids.

Turner, D.L., 2008, Baker Exegetical commentary on the New Testament: Matthew, Baker Academic, Grand Rapids.

Vlach, M.J., 2014, 'God's kingdom and the miraculous', The Master's Seminary Journal 25(2), 29-43.

Wenham, G.J., 1979, The book of Leviticus, Eerdmans, Grand Rapids. 